\title{
Experimental study of the use of electric car powered with stationary solar and electrochemical batteries in Northern Poland
}

\author{
Dariusz Karkosiński 1,*, Michat Pacholczyk ${ }^{1}$, and Lukasz Sienkiewicz ${ }^{1}$ \\ ${ }^{1}$ Gdańsk University of Technology, Faculty of Electrical and Control Engineering, Laboratory of Innovative Power Technologies and \\ Integration of Innovative Energy Sources: LINTE^2, ul. Sobieskiego 5, 80-216, Gdańsk, Poland
}

\begin{abstract}
The subject of this paper is an experimental analysis of a Nissan LEAF electric car equipped with $24 \mathrm{kWh}$ battery, powered from the standalone photo-voltaic (PV) charging station in Gdańsk, Poland. The calculations of charging process efficiency and range of test drives were conducted in two extreme situations (winter and summer) of sunlight and road conditions. Experiments were performed in the Laboratory of Innovative Power Technologies and Integration of Innovative Energy Sources (LINTE^2) at Gdańsk University of Technology. The car was night-charged with the stationary electrochemical battery, which, in turn, was powered with PV panels during the day. The impact of sunlight and ambient temperature changes on daily urban and highway drive ranges was analysed. The efficiency of energy conversion in multiple current converters was determined.
\end{abstract}

\section{Properties of electric vehicles: charging process and usage}

Electric vehicles (EV) were one of the first car for carrying people. In the years 1832 - 1839 the first carriages and cars with the voltaic pile were announced and tested. Between 1859 and 1871, vehicles with a lead-acid battery and a DC motor were built. EVs were produced along with the steam engines vehicles. Internal combustion engines have not been in use yet. At the beginning of the twentieth century, they EVs were pushed out of the market by vehicles with internal combustion engines, including the Ford $\mathrm{T}$, mass produced from 1908 to 1912. Developing oil lobby has later lead to the almost complete collapse of the EV concept.

The present decade should be considered as a breakthrough in the worldwide development of technology and sales of electric cars. Further advancements in power electronics [1] and the evolution of the EV propulsion battery (from lead-acid to almost exclusively higher efficiency, lighter and characterized by low self-discharge rate lithium battery $[2,3]$ ) can be considered as factors that brought the industry's attention back to electric vehicles. However, the environmental concerns in terms of greenhouse gases (GHG) emissions can also be identified as a major accelerator of the EV market [2]. As reported in [4] the transportation sector in 2012 consumed almost $27 \%$ of the global energy production and was responsible for $33.7 \%$ GHG emissions. Replacement of the conventional and inefficient internal combustion engine vehicles
(ICEV) with hybrid electric vehicles (HEV) and all electric vehicles including battery electric vehicle (BEV) and fuel cell electric vehicle (FCEV) can be a way to not only limit emissions but also to provide cleaner and quieter ambiance as well as to drastically reduce the operational cost compared to gas-powered cars [5]. Since HEV use both electric motor (EM) and ICE to move a vehicle and FCEV face problems with hydrogen storage, $\mathrm{BEV}$ are the most interesting regarding environmental protection and in this paper the definition of $\mathrm{EV}$ refers to that kind of vehicles.

Although promising, EV capabilities are still limited, additional and continuous development is required to confront market's needs. The specific characteristics of modern electric vehicles include:

a. Replacement of combustion engine vehicle with an EV shifts the emissions from the car to the power plant. Moreover, charging car batteries from a central power station is more efficient than burning fuel in separate engines [6]. Unless produced in a "green" way, GHG are still emitted;

b. Electric vehicles do not emit pollutants while in use but due to not yet fully mature technology and high utilization of rare earth metals, the production process generates much more emissions compared with the ICE cars production process;

c. Limited real drive range: under $250 \mathrm{~km}$ for cheaper models and above $400 \mathrm{~km}$ - only for the most expensive ones; with electric heating or air-conditioning decreasing the range drastically. Regenerative breaking is often used

\footnotetext{
* Corresponding author: dariusz.karkosinski@pg.edu.pl
} 
to increase the range. Battery can be also supplemented with additional energy sources e.g. vehicle-integrated PV [7];

d. Long charging time of the battery pack: 10-12 hours from home grid and not shorter than 20 minutes from fast charging stations;

e. The battery capacity drops to approximately $50 \%$ under $-20{ }^{\circ} \mathrm{C}$;

f. The asking price of an electric vehicle is much higher than the combustion engine equivalent. The huge part of the EV cost lies in battery pack which can exceed $45 \%$ of total vehicle cost [8]. On the other hand, electric cars are much simpler and have fewer parts compared to existing vehicles, [6];

g. Limited durability of the battery pack - approx. $200,000 \mathrm{~km}$ or 10 years with high replacement cost. The driving range is decreasing due to the wear of the battery pack;

h. The drive range of EVs also depends on the rolling resistance caused by deflection - the flattening of the tires. In every kind of car, the reduced pressure, e.g. by 0.5 bar, increases the rolling resistance by about $15 \%$, which in electric cars translates into a proportional reduction of range.

There are a few models of EVs on the polish market. One of the bestselling models is Nissan LEAF (Leading, Environmentally friendly, Affordable, Family car produced since 2010). Nissan LEAF (2015 model tested by authors: fig. 1) can be charged via $3 \mathrm{~kW}$, slow charger (charging duration $8 \mathrm{~h}$ ), $44 \mathrm{~kW}, 480 \mathrm{~V} \mathrm{DC}$ fast charger (up to $80 \%$ of capacity in $30 \mathrm{~min}$ ) in SchAdeMO standard or via $16 \mathrm{~A}, 230 \mathrm{~V}$ AC home grid $(12 \mathrm{~h})$. The producer gives the rated power of the permanent magnet motor as $80 \mathrm{~kW}$, while the maximal power given by the manufacturer is $90 \mathrm{~kW}$. The capacity of car's battery pack is $24 \mathrm{kWh}$.

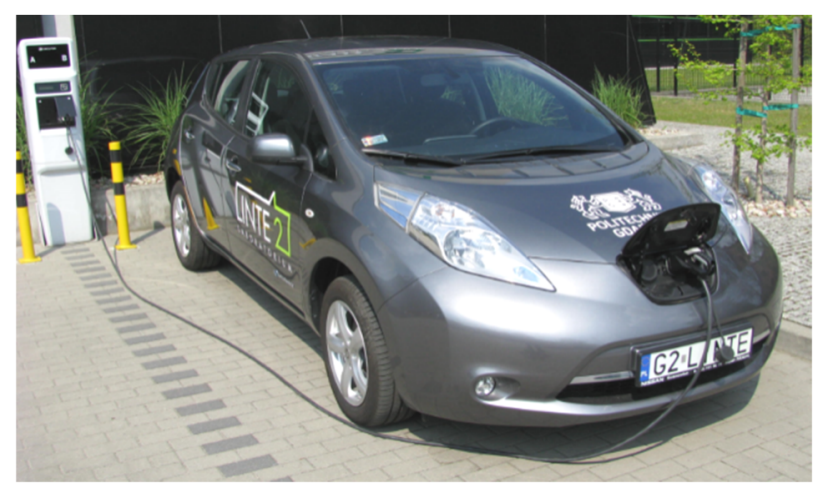

Fig. 1. Nissan Leaf tested by authors.

\section{Use of solar power plants for charging electric vehicles}

One of the main issues that EVs have to face is that related to charging. Beside cost of the battery pack and charging duration, common availability and accessibility of the charging facilities is another challenge [1]. Especially in Poland, the development of electro- mobility requires a huge investment in the construction of an automobile charging station infrastructure. Clearly, along with EV's market growth more charging stations will be installed. That however, along with increasing number of EVs, will impose extra burden on electrical utility due to the large current drawn from grid while charging [7]. To cope with rising demand, smart grids with renewable energy sources are seen as one of the main sources for charging stations [9].

Among them, solar power can be recognized as competitive since the price of PV modules is still falling [10]. Furthermore, solar technology is found reliable and almost maintenance free. Numerous charging methods using PV have been proposed. However, approaches called PV-grid and PV-standalone are currently most wide-spread.

The first one refers to the combination of PV and the grid, which during insufficient irradiance ensures continuity of the charging process [2]. Produced power can also feed electrical utility while no EV is present at the charging station. PV-grid charging system can operate in the following modes:

a. Mode 1 - EV charged by PV alone;

b. Mode 2 - EV charged by grid alone, inverter in rectification mode;

c. Mode 3 - EV charged by both PV and grid: inverter in rectification;

d. Mode 4 - no charging: inverter in inversion generated power is transferred to grid;

e. Mode 5 - Vehicle to grid: inverter in inversion. Although attractive, this process can shorten the EV's battery life.

In the second approach it is proposed to use the PV solely with no grid connection. This approach is known as the PV-standalone charger $[5,11]$. It is particularly convenient in remote areas where utility supply is too expensive or not available at all [2]. In a typical set-up, the charger is not directly powered by PV but via an intermediate storage battery bank. This is due to the fact that mass produced electric cars communicate with a charger using the Master-Slave model, where the charger is the slave unit. It means, that the car "demands" specific charging power and the charger supplies it. In the case of power being fed directly from the solar power plant, even a temporal overcast limits the supplied power and usually interrupts the charging process, which then has to be re-activated. Additionally, a battery bank enables to utilize the charger when there is no sun e.g. at night [12]. It smooths out the abrupt changes in the PV output power as well [13]. Recently, hybrid PV standalone systems have been introduced [10, 13-16]. The hybrid system consists of a PV generator and secondary power source e.g. fuel cell.

In the context of charging methods that utilize PV, the northern areas of Poland, including Gdańsk, are a big challenge, due to their location at $54^{\circ}$ north latitude. They are characterized by low solar radiation compared to the southern parts of Poland and Europe, where solar power plants are much more efficient. Moreover, the large annual variation of solar irradiance is also characteristic for Gdańsk (fig. 2). 


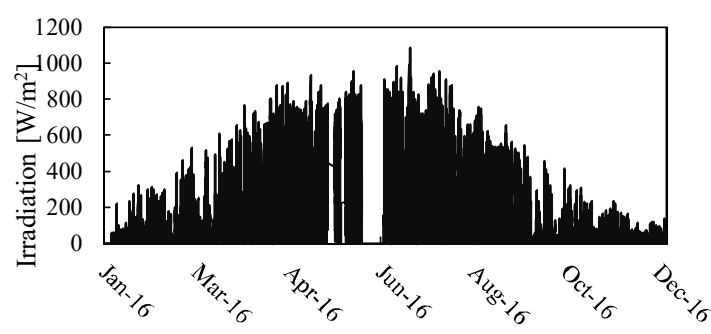

Fig. 2. Annual irradiation in Gdańsk (Breaks due to lack of service of weather stations).

Therefore, the authors conducted an experimental analysis of charging EV from the PV-standalone system with a battery pack for two extremely different weather conditions. Trials with charging an EV from the battery pack (charged by PV) through a slow charger (8h) in winter and through a fast charger (30 minutes to $80 \%$ capacity) in summer were performed. The experimental analysis was conducted in the Laboratory of Innovative Power Technologies and Integration of Innovative Energy Sources (LINTE^2). Extensive laboratory equipment within LINTE`$^{\wedge} 2$ allows the researchers to freely configure various types of sources and energy storages, as well as to create physical models of transmission lines. The study of modern power systems for EVs composed of 3 solar power plants with a rated powers of $5 \mathrm{~kW}, 8 \mathrm{~kW}$ and $20 \mathrm{~kW}$ and an electrochemical battery with capacity of $25 \mathrm{kWh}$ can be performed. LINTE $^{\wedge} 2$ is also equipped with Nissan LEAF EV, which can be powered via the fast $\mathrm{DC}$ and slow AC chargers.

A scheme presenting a part of the laboratory's infrastructure is shown in fig. 3. The solar power plant installed on the laboratory's roof consists of three photovoltaic packs of panels, each with different rated power. The PV inverters were connected through appropriate contactors with the bidirectional converters of the stationary battery pack during the day. Winter and summer tests of charging and driving cycles were conducted.

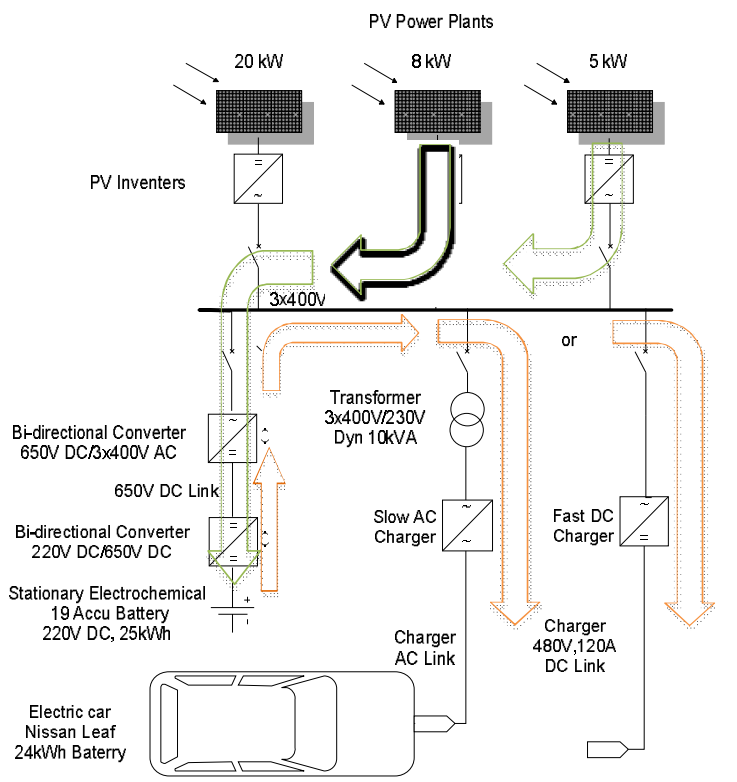

Fig. 3. Experimental setup using $\operatorname{LINTE}^{\wedge} 2$ infrastructure.
As shown in fig. 4, the highest irradiance of the sun on a clear day in January did not exceed $250 \mathrm{~W} / \mathrm{m}^{2}$ and on cloudy day $100 \mathrm{~W} / \mathrm{m}^{2}$. The effective working time of the solar power plant did not exceed 5 hours per day. Figures 6 and 7 show fragments of the battery charging cycle (from the total discharge state) fed from the solar power plant on a sunny day (irradiation profile marked by a solid line in fig. 4). Plots marked as PV (fig. 6 and 7) correspond to the $\mathrm{AC}$ power generated by the three inverters of the solar power plant. Plots marked as stationary electrochemical battery pack (BA) correspond to the charging power (DC) of the electrochemical battery pack. The difference between PV and BA shows the losses of conversion from alternating current (AC) to direct current (DC). As can be seen, the charging power ranged from 2 to $7 \mathrm{~kW}$ with interruptions caused by transient overcasts. The power of the losses is practically constant at about $1.5 \mathrm{~kW}$. The energy supplied to stationary the battery pack during a sunny day in January was $11.4 \mathrm{kWh}$.

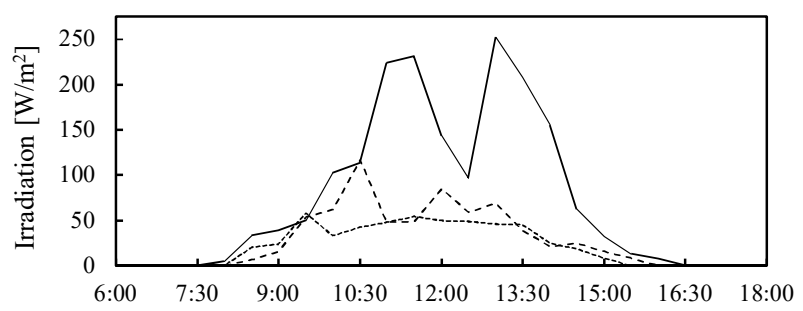

Fig. 4. Examples of daily irradiation profiles in Gdańsk for 3 January days with different overcast.

\section{EV charging and test drives}

Driving tests were performed for each of the two seasons (winter, summer), in two extreme driving conditions. The first one was the "eco" mode for urban driving and the second one was the highway dynamic mode - with "eco" mode off. In addition, the pressure was lowered in the summer tires.

During the winter tests, the Nissan LEAF was charged from a stationary battery pack with a slow charger. The process was started at dusk. A part of the charging plot is presented in fig. 5. The power supplied was $3.5 \mathrm{~kW}$, at the battery pack power level of $5 \mathrm{~kW}$. In this case conversion losses were also about $1.5 \mathrm{~kW}$. Charging ended automatically after the discharge of the battery pack, i.e. after 3 hours and 48 minutes. At that time, the energy accumulated in the car's battery increased by $10.2 \mathrm{kWh}$.

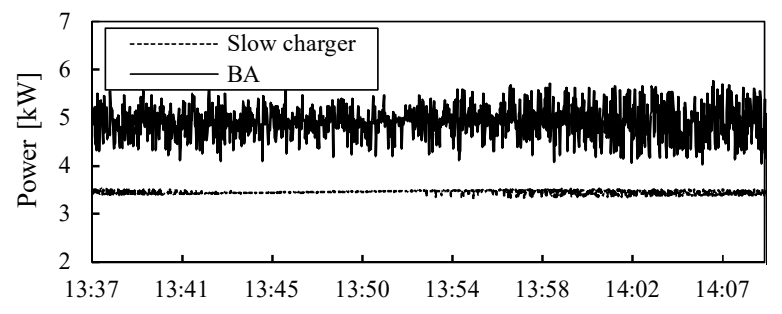

Fig. 5. EV Charging with stationary battery pack (BA) via slow charger - fragment. 


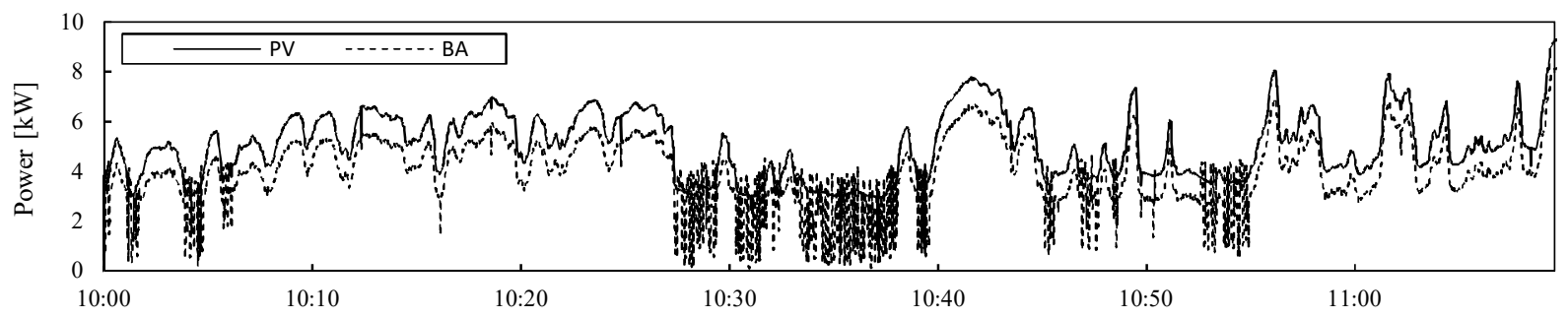

Fig. 6. Stationary battery pack (BA) charging from PV plant $(20+8+5 \mathrm{~kW})$ on January morning (fragment).

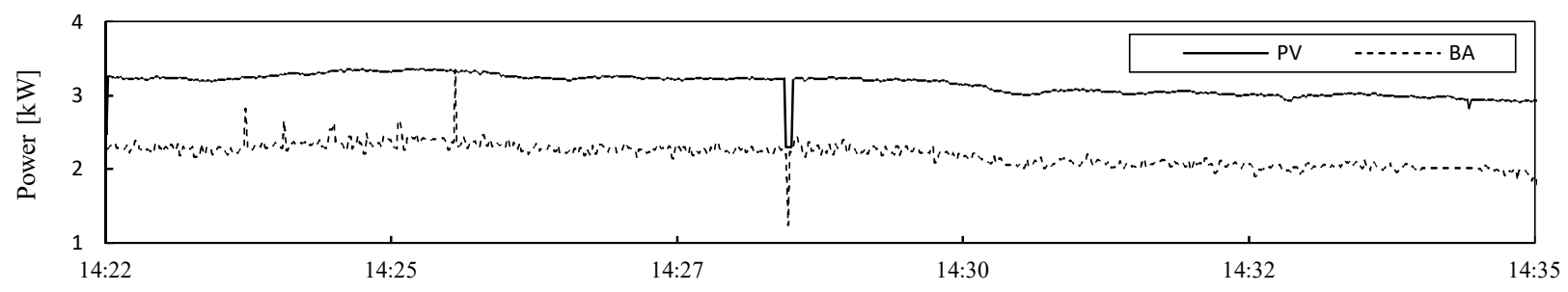

Fig. 7. Stationary battery pack (BA) charging from PV plant $(20+8+5 \mathrm{~kW})$ on January afternoon (fragment).

During the summer tests Nissan LEAF was charged from the stationary battery pack with a quick charger. Fragments of the power plots for the following stages of the test configuration are shown in fig.8. The quick charger began charging with a power of about $36 \mathrm{~kW}$, which resulted in loading of the battery pack with 44 $\mathrm{kW}$. Although the charging power was rapidly decreasing, the losses of multiple current conversions were constant and amounted to approximately $8 \mathrm{~kW}$. The biggest losses were measured at $650 \mathrm{~V}$ DC Link to $3 \times 400 \mathrm{~V}$ AC Busbar conversion stage. The charging process was interrupted after 30 minutes, i.e. after reaching $80 \%$ of EV's capacity, which is approximately $19 \mathrm{kWh}$.

The current and voltage plots in the individual charging stages (fig. 9) indicate that the charging of the car caused the discharge of the battery pack with $175 \mathrm{~A}$ DC. This resulted in a fairly rapid decrease of voltage level at battery terminals. At $650 \mathrm{~V} \mathrm{DC}$ stage, the current and voltage were almost constant. Despite this, the voltages at $3 \times 400 \mathrm{~V} \mathrm{AC} \mathrm{Busbar} \mathrm{and} \mathrm{charger's} \mathrm{DC} \mathrm{Link}$ stages increased as the charging current decreased.

Based on the analysis above, the current conversion efficiency from a solar power plant to a car battery through a stationary battery pack using a slow charger can be estimated at a $54 \%$. The efficiency increased to $78-81 \%$, when a fast charger was utilised.

During the test drives, the drive route, the mechanical and electrical parameters of the EV were recorded. Parameter registration and vehicle position data was performed using a mobile device running Leaf Spy Pro application under the Android environment. The application communicates wirelessly with the adapter connected to the vehicle's internal CAN network via the OBDII connector, from which measurement data is collected and stored in the internal memory of the mobile device.

Additionally, the position and accurate speed of the vehicle is recorded using the GPS receiver of the mobile device. A Windows application "LeafLog" has been developed to allow reading, presentation and analysis of the collected measurement data.

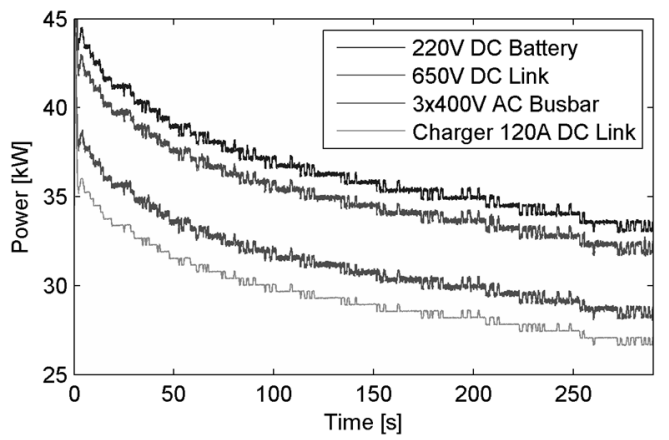

Fig. 8. Charging of EV through battery pack with the fast charger. Power of the following stages (fragment).
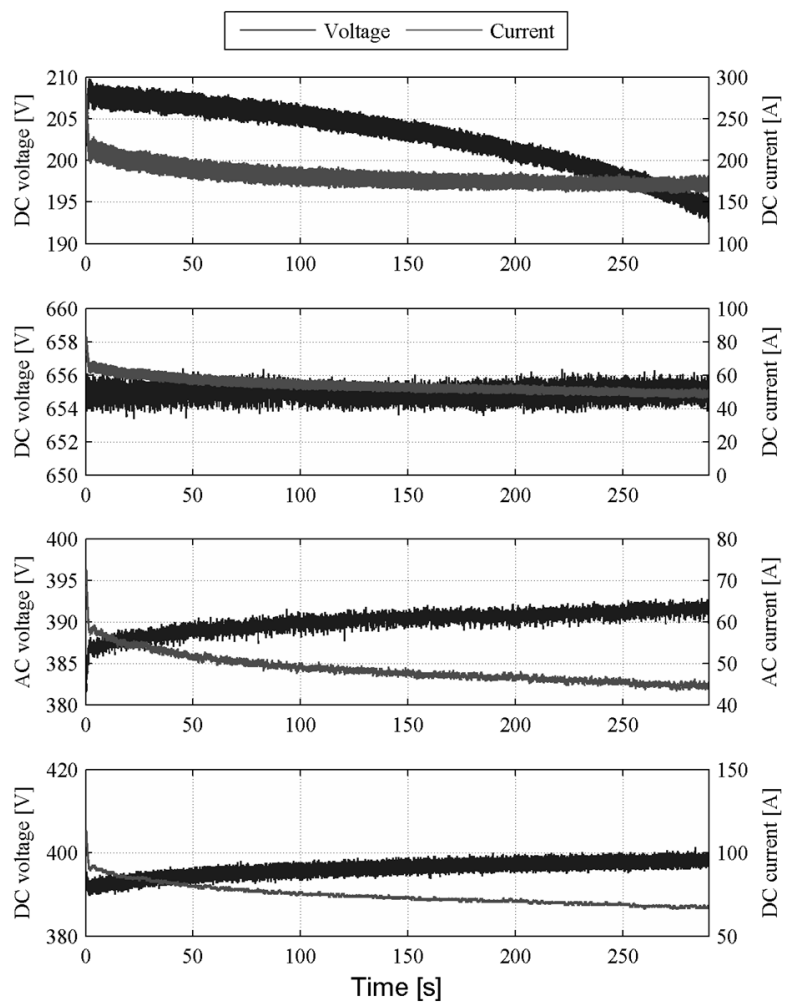

Fig. 9. The current and voltage plots for fast charging a) $220 \mathrm{~V}$ DC Battery b) 650V DC Link c) 3x400V AC Busbar d) 120A DC Link of the Charger. 


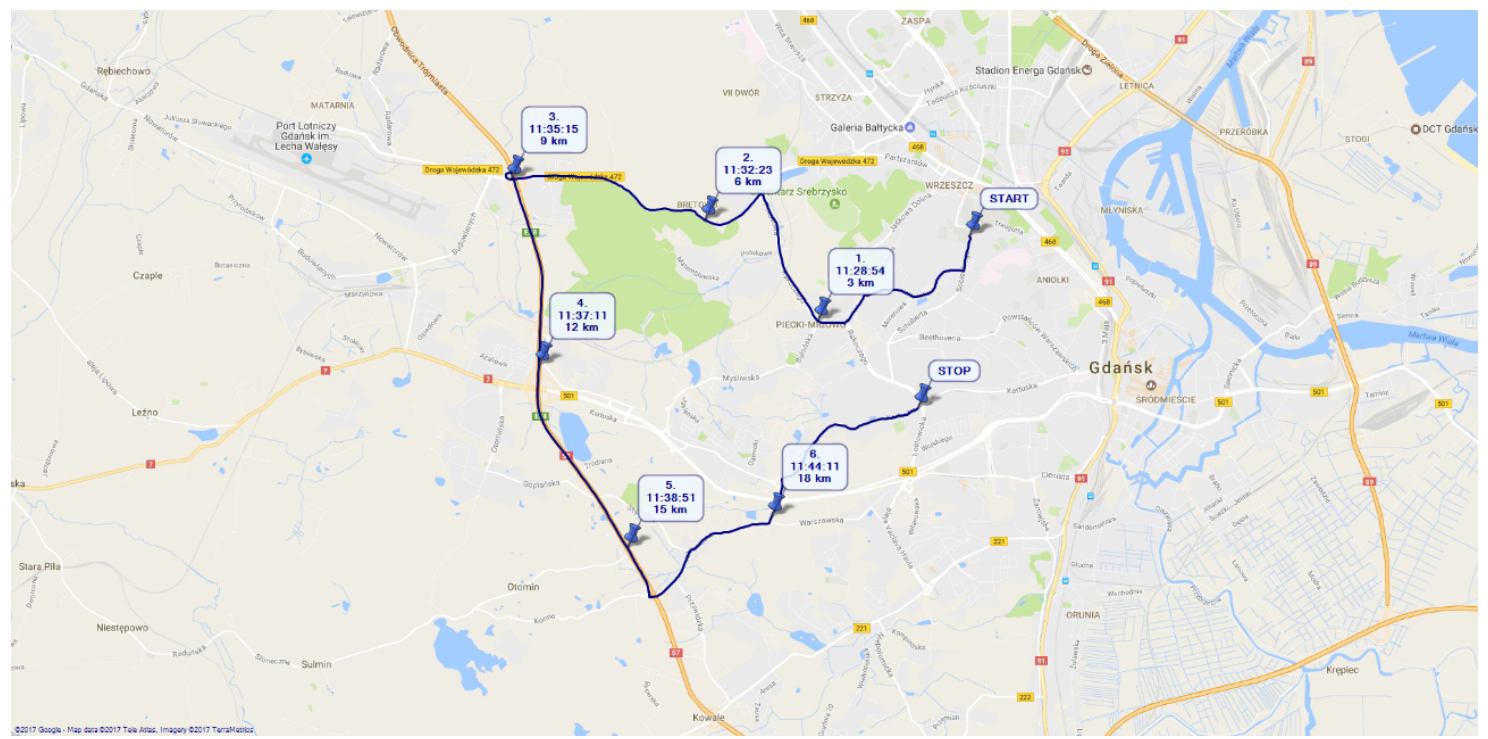

Fig. 10. An example of the test drive route.

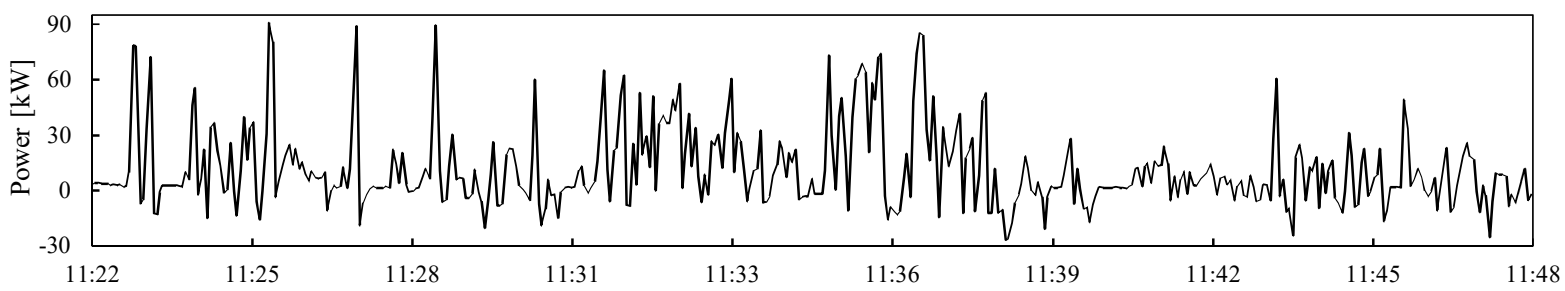

Fig. 11. Example of eco mode test drive; EV battery power.

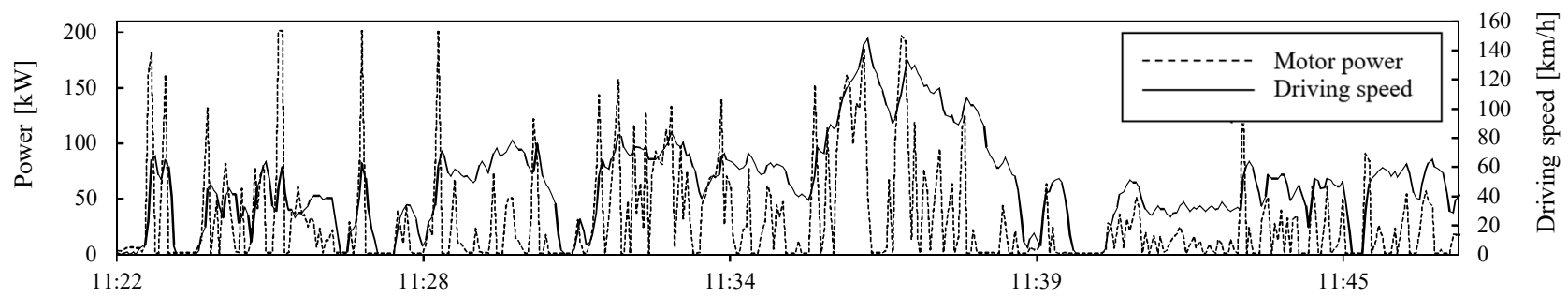

Fig. 12. Example of dynamic mode test drive; engine power $[\mathrm{kW}]$ and speed $[\mathrm{km} / \mathrm{h}]$.

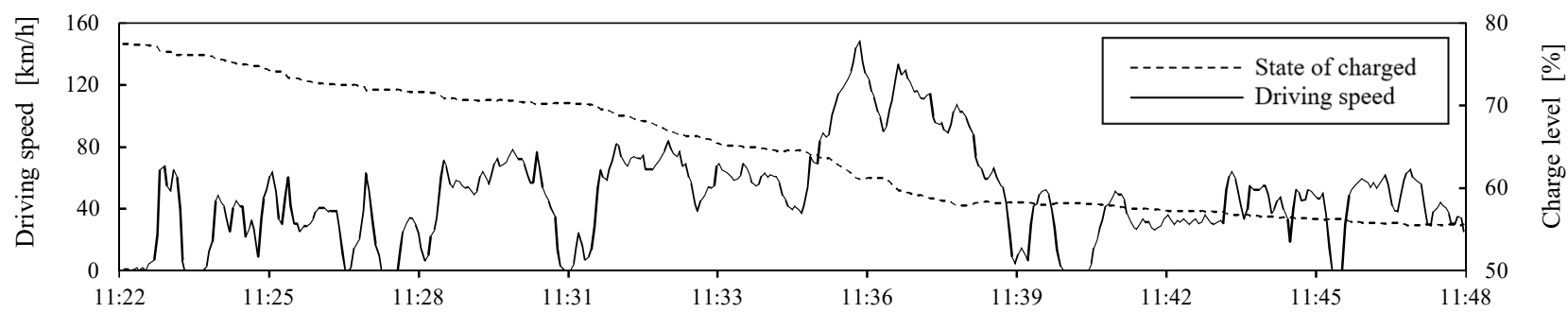

Fig. 13. Example of dynamic mode test drive; speed [km/h] and EV's battery level [\%].

An example of a test drive route including selected streets in Gdańsk is presented in fig. 10. Figures 11, 12 and 13 present examples of registered EV parameters. As shown in the fig. 11, the maximal motor power in eco mode reaches $90 \mathrm{~kW}$ and during regenerative braking $30 \mathrm{~kW}$. The parameters shown in Table 1 were estimated on the basis of 20 winter Nissan Leaf test drives made in January and 10 summer drives. The test drives were conducted around noon (before the rush hours) in typical urban traffic and on the highway.

This means that even in the short but sunny January days in the Gdańsk area, authors were able to use the EV completely free of charge (due to the solar energy utilization) through $29 \mathrm{~km}$ on the Tricity (Gdańsk Sopot - Gdynia) Highway and $49 \mathrm{~km}$ in urban traffic. However, this required the use of a solar power plant with a rated output of $33 \mathrm{~kW}$. This range could be significantly increased after optimization of current conversion losses by the elimination of multiple current conversions.

The summer tests revealed that after 30 minutes of charging the accumulated energy from the solar battery it is possible to use the EV through $100 \mathrm{~km}$ on the Tricity Highway and $146 \mathrm{~km}$ in urban traffic. This range would increase slightly after optimization of current conversion losses. 
Table 1. Results of test driving - Nissan LEAF (2015 model).

\begin{tabular}{|c|c|c|c|c|}
\hline & \multicolumn{2}{|c|}{ January - 20 tests } & \multicolumn{2}{|c|}{ July/August - 10 tests } \\
\hline $\begin{array}{l}\text { Average ambient } \\
\text { temperature }\end{array}$ & \multicolumn{2}{|c|}{$+1^{0} \mathrm{C}$} & \multicolumn{2}{|c|}{$+24^{0} \mathrm{C}$} \\
\hline $\begin{array}{c}\text { Other activated } \\
\text { devices }\end{array}$ & \multicolumn{2}{|c|}{$\begin{array}{l}\text { heating, wipers, heated } \\
\text { window, daily lights }\end{array}$} & \multicolumn{2}{|c|}{$\begin{array}{l}\text { air conditioning, daily } \\
\text { lights }\end{array}$} \\
\hline People on board & \multicolumn{2}{|c|}{ Driver $\& 3$ passengers } & \multicolumn{2}{|c|}{ Driver \& 1 passenger } \\
\hline Tires, pressure & \multicolumn{2}{|c|}{$\begin{array}{c}\text { Barum Winter } \\
2.49 \mathrm{Bar} \\
\end{array}$} & \multicolumn{2}{|c|}{$\begin{array}{c}\text { Michelin EnergySaver } \\
2.57 \mathrm{Bar} \\
\end{array}$} \\
\hline Type of drive & $\begin{array}{l}\text { Urban } \\
\text { eco mode }\end{array}$ & $\begin{array}{l}\text { Highway } \\
\text { dynamic } \\
\text { mode }\end{array}$ & $\begin{array}{c}\text { Urban } \\
\text { eco mode }\end{array}$ & $\begin{array}{l}\text { Highway } \\
\text { dynamic } \\
\text { mode }\end{array}$ \\
\hline Average velocity & $31 \mathrm{~km} / \mathrm{h}$ & $87 \mathrm{~km} / \mathrm{h}$ & $35 \mathrm{~km} / \mathrm{h}$ & $113 \mathrm{~km} / \mathrm{h}$ \\
\hline $\begin{array}{c}\text { Energy } \\
{[\mathrm{kWh} / \mathrm{km}]}\end{array}$ & 0.21 & 0.35 & 0.13 & 0.19 \\
\hline $\begin{array}{c}\text { Driving range } \\
\text { for one charge } \\
(10.2 \mathrm{kWh})\end{array}$ & $49 \mathrm{~km}$ & $29 \mathrm{~km}$ & - & - \\
\hline $\begin{array}{c}\text { Driving range } \\
\text { for one charge } \\
80 \% \\
(19 \mathrm{kWh}) \\
\end{array}$ & - & - & $146 \mathrm{~km}$ & $100 \mathrm{~km}$ \\
\hline $\begin{array}{c}\text { Predicted range } \\
\text { for } 100 \% \\
\text { capacity }\end{array}$ & $114 \mathrm{~km}$ & $69 \mathrm{~km}$ & $185 \mathrm{~km}$ & $126 \mathrm{~km}$ \\
\hline
\end{tabular}

\section{Conclusions}

In order to carry out research on the efficiency of charging an electric car from a solar power plant, part of the infrastructure of the $\operatorname{LINTE}^{\wedge} 2$ Laboratory of the Gdańsk University of Technology was used. It included: a solar power plant with a total rated power of $33 \mathrm{~kW}$, a stationary battery pack of $25 \mathrm{kWh}$ and a Nissan Leaf EV with a battery capacity of $24 \mathrm{kWh}$. As a result of the research, it was determined that the solar energy collected at worst winter conditions, but in a sunny day in northern Poland area, allows for about $30 \mathrm{~km}$ of a highway dynamic driving and about $50 \mathrm{~km}$ drive in urban eco mode without any costs of energy. For $100 \%$ of the EV battery capacity, the extended range would be adequate for $70 \mathrm{~km}$ and $115 \mathrm{~km}$ drives. In the best summer conditions one quick charge to the $80 \%$ capacity allowed the authors to drive in urban eco mode $146 \mathrm{~km}$ and dynamic highway on $100 \mathrm{~km}$ on average. The predicted summer range for a fully charged battery $(100 \%)$ at of the EV is adequate for $185 \mathrm{~km}$ and $126 \mathrm{~km}$.

The result of power registers during dynamic driving - Fig. 12 - is very interesting. It latches on the car drive maximum power of $200 \mathrm{~kW}$. The manufacturer does not specify this value and gives a maximum power of 90 $\mathrm{kW}$. Despite long-lasting and very dynamic driving, the authors failed to activate the thermal limitation of this power.

\section{References}

1. F. S. Tie, C. W. Tan, A review of energy sources and energy management system in electric vehicles, Renewable and Sustainable Energy Review, 20, 82102, (2013)

2. R. Bhatti, et al., Electric vehicles charging using photovoltaic: Status and Technological Review,
Renewable and Sustainable Energy Review, 54, 3447, (2016)

3. Xiaopeng, et all., An overview of lithium-ion batteries for electric vehicles, Proceedings of IPEC Conference on Power \& Energy, 230-235, (2012)

4. R. Schmidt, Information technology energy usage and our planet. Thermal and Thermomechanical Phenomena in Electronic Systems, ITHERM, (2008)

5. Abu-Jasser, A stand-alone photovoltaic system, case study: a residence in Gaza, Journal of Applied Sciences in Environmental Sanitation, 5:81-91, (2010)

6. "Roadkill", 7-8, (The Economist, 12.08.2017)

7. Kelman, Supporting increasing renewable energy penetration in Australia - the potential contribution of electric vehicles, Proceedings of 20th Australasian Universities Power Engineering Conference, 1-6, (2010)

8. S. E. Letendre, Vehicle integrated photovoltaic: exploring the potential, Proceedings of the 23rd International Electric Vehicle Symposium, (2007)

9. Z. Li, et al., Optimal charging control for electric vehicles in smart microgrids with renewable energy sources, 2012 IEEE 75th Vehicular Technology Conference, 1-5, (VTC Spring, Yokohama, 2012)

10. P. P. Barker, J. M. Bing, Advances in solar photovoltaic technology: an applications perspective, Proceedings of Power Engineering Society General Meeting, Vol. 2, 1955-1960, (2005)

11. S. J. Chiang, S. Hsin-jang, C. Ming-chieh, Modelling and Control of PV Charger System with SEPIC Converter, IEEE Transaction of Industrial Electronics, 56:43-53, (2009)

12. S. Mesentean, et al., Smart charging of electric scooters for home to work and home to education transports from grid connected photovoltaic system, Proceedings of IEEE International Energy Conference and Exhibition, 73-78, (2010)

13. J. MOSSOBA, et al., Analysis of solar irradiance intermittency mitigation using constant $D C$ voltage $P V$ and EV battery storage, Proceedings of IEEE Transportation Electrification Conference and Expo, $1-6$, (ITEC, 2012)

14. M. Robalino, et all., Design of a docking station for solar charged electric and fuel cell vehicles, Proceedings of the International Conference on Clean Electrical Power, 655-660, (2009)

15. Z. Mokrani, D. Rekioua, T. Rekioua, Modelling, control and power management of hybrid photovoltaic fuel cells with battery bank supplying electric vehicle, International Journal of Hydrogen Energy, 39: 15178-15187, (2014)

16. R. Parsons, et al., Willingness to pay for vehicle to grid (V2G) electric vehicles and their contact terms, Energy Economics, Vol. 42, 313-324, (2014) 